\title{
The Effect of Pedagogical Competence, Attitude Towards Profession And Motivation on Teachers Performance
}

\author{
Suhaimi ${ }^{1}$, Ma'ruf Akbar ${ }^{2}$, Hasbi Sjamsir ${ }^{3}$ \\ \{amysuhaimi057@yahoo.co.id ${ }^{1}$, makrufakbar@unj.ac.id ${ }^{2}$, sjamsirhasbi@yahoo.com ${ }^{3}$ \\ Universitas Negeri Jakarta, Indonesia ${ }^{12}$ \\ Universitas Negeri Mulawarman, Indonesia ${ }^{3}$
}

\begin{abstract}
The purpose of this study is to investigate the effect of pedagogical competence, attitude towards profession, as well as work motivation on the performance of teachers of Islamic elementary schools in Samarinda. The results of the research reveals that pedagogical competence, attitude towards profession, and motivation, all have a direct positive effect on teachers performance. Research samples were 148 teachers randomly selected. Data was collected using questionnaire instruments, and analyzed through the path analysis techniques. Based on the results of the research, pedagogical competence, attitude towards profession and motivation, all have a direct positive effect on the performance of teachers of Islamic elementary schools.
\end{abstract}

Keywords: Pedagogical Competence, Attitudes towards Profession, Motivation and Teacher Performance.

\section{Introduction}

Teachers' teaching technique, is very influential as it contributes to the quality of education received by a student. This will in return produce quality human resources which accelerates the achievement of the society welfare. Robbin (1994) defined performance as a description of the quantity and quality of work achieved, or performed by individuals, groups or companies[1]. Furthermore, Cascio \& Aguinis (2014) stated that performance is an individual's behavior relevant to the goals of an organization, which increases or decreases the effectiveness of the organization from a certain position, especially in the form of task completion behavior which is in line with the roles stated in the job description [2].

This is pertinent with Moorhead and Griffin (2005) who pointed out that work process requires individual performance behavior. Work behavior is a series of individual work-related behaviors expected by an organization[3]. Considering the description there are two views about performance, namely thinking of it as a work process or behavior and as a result of work. The performance of teachers of Islamic elementary schools in Samarinda has not been optimum. Based on the empirical data, the evaluation result on teacher's shows that $25 \%$ of teachers posses good teaching skills, $51 \%$ posses lower skills, while $14 \%$ of teachers are in the fair and moderate grades. 
Pedagogic competence influences teacher performance. It is a teacher's capability to understand students and deliver the teaching and learning appropriately. Giertz (2010) defined pedagogical competence as the ability and desire to regularly apply the attitude, knowledge and skills that promotes students learning[4].

The teacher must also have a good attitude towards his work. Moorhead and Griffin (2013) affirms that attitude is a set of beliefs and feelings that a person has about certain ideas and situations or about others. It is important because it is a mechanism used by most people to express their feelings[5]. Thomas and Znaniecki stated that with our attitude we tend to understand the process of individual consciousness which helps to determine real activities or possible individual actions in the social world [6]. The view is pertinent with the attitude function stated by Katz (1960), Smith, Brunner \& White (1956) and Harek (1986) who concluded that there are five important attitude functions. These include (1) attitude as an instrumental function, (2) attitude as a function of expressive value (3) attitude as a function of ego defense, (4) attitude as a function of social adjustment and (5) function of attitude as behavior[7].. Rosenberg and Hovland divided these into three components known as tripartite models as follows: (1) Cognitive component (perceptual component), (2) Affective component (emotional component), 3 Conative components (behavior component or action component) [8].

Teachers must be motivated to carry out their jobs. George R. Terry (2006) defined motivation as a desire that exists in someone and induces them to take actions[9]. Gleitmen and Reber (2004) considered motivation as an energizer or power supplier. It is internal state of both human and animal organism, which encourages them to do something[10]. Work motivation encourages the teacher who aims at carrying out the task responsibly.

\section{Methodology}

The method used in carrying out this research is the quantitative research using a survey and a casual approach. The results of the survey were analyzed using multivariate statistics with path analysis techniques. The total population of data used is 343 teachers of Islamic elementary schools in Samarinda City, East Kalimantan. 148 teachers was selected using Slovin simple random formula. Data collection is done through tests and questionnaires using a Likert scale. Data set See at : https://osf.io/9bqpm/ )

\section{Result}

The results of the normality test analysis shows that the data were normally distributed. Estimated error testing in the regression equation $\mathrm{Y}$ on $\mathrm{X} 1(\hat{\mathrm{Y}}=99,147+0,629), \mathrm{Y}$ on $\mathrm{X} 2$ $(\hat{Y}=94,963+0,156), Y$ on $X 3(\hat{Y}=72,278+0,465)$ was carried out using a degree of trust $\alpha=$ 0.05 with a total sample of $148=0.07281$. This was used to determine the effect between variables linearity test. 
3.1 Linearity and Significance of Regression Coefficients of Teacher Performance (Y) on Pedagogic Competence (X1).

From the results of regression calculations, F-count $=26.356$ and F-table for $\alpha=$ 0.01 degrees of freedom $(1,146)$ resulting in F-table $=3.92$. Since F-count $>$ F-table, Ho is rejected. It indicates that the regression is very significant. In the linearity test of a simple regression equation, the calculation result shows that the value of F-count $=-4.609$ and F-table at $\alpha=0.05$ degrees of freedom $(40,106)$ the obtained F-table $=$ 1.54. Due to the fact that F-count $\geq$ F-table, Ho is accepted. It means that the regression equation of teacher's performance $(\mathrm{Y})$ to pedagogical competence (X1) is linear and significant.

\subsection{Linearity and Significance of Regression Coefficients of Teacher Performance (Y) on} Attitudes towards Profession (X2)

From the results of regression calculations, F-count $=31.954$. F-table for $\alpha=0.05$ degrees of freedom $(1,146)$, the obtained F-table is 3.92. Since F-count $>$ F-table, Ho is rejected, which means that the regression is very significant. In the linearity test of a simple regression equation, the calculation results show the value of F-count = 0.654 and F-table at $\alpha=0.05$ degrees of freedom $(62,84)$ it is found that F-table is 1.45. Since F-count $\leq$ F-table, Ho is therefore accepted. It indicates that the regression equation of teacher performance $(\mathrm{Y})$ on attitude towards profession $(\mathrm{X} 2)$ is linear and significant.

\subsection{Linearity and Significance Regression Coofficients of Teacher Performance (Y) on Teacher's Work Motivation (X3)}

From the results of regression calculations, the obtained F-count is 28.835 for $\alpha=$ 0.05 and F-table $=3.92$. Since F-count $>$ F-table, the regression is significant. In the linearity test of a simple regression equation, the calculation results refers to the value of F-count $=-0.973$ and F-table $=5.66$ at $\alpha=0.05$. Since F-count $\leq$ F-table, the regression equation model of teacher work motivation (X3) on teacher performance (Y) is linear and significant. To find out the relationship between variables a correlation test was conducted.

Table 1. Correlation Matrix between Variables

\begin{tabular}{llllll}
\hline & & \multicolumn{1}{c}{ Y } & X1 & X2 & X3 \\
\hline Y & Pearson Correlation & 1 & $.391^{* *}$ & $.424^{* *}$ & $.406^{* *}$ \\
& Sig. (2-tailed) & & .000 & .000 & .000 \\
& N & 148 & 148 & 148 & 148 \\
X1 & Pearson Correlation & $.391^{* *}$ & & & \\
& Sig. (2-tailed) & .000 & & & \\
& N & 148 & & & \\
X2 & Pearson Correlation & $.424^{* *}$ & & & \\
\hline
\end{tabular}




\begin{tabular}{lll}
\hline & Sig. (2-tailed) & .000 \\
& $\mathrm{~N}$ & 148 \\
$\mathrm{X} 3$ & Pearson Correlation & $.406^{* *}$ \\
& Sig. (2-tailed) & .000 \\
$\mathrm{~N}$ & 148 \\
\hline
\end{tabular}

Furthermore, the matrix correlation coefficient becomes the basis for calculating the path coefficient analysis. For this reason, T. Test is used. The calculation results on path coefficients.

Table 2. Path Coefficient

\begin{tabular}{llcc}
\hline \multicolumn{1}{c}{ Path } & & Path Coefficient & t-count \\
\hline $\mathbf{X}_{\mathbf{1}} \mathbf{Y}$ & $\mathrm{P}_{\mathrm{y} 1}$ & 0,629 & 5,134 \\
$\mathbf{X}_{\mathbf{2}} \mathbf{Y}$ & $\mathrm{P}_{\mathrm{y} 2}$ & 0,156 & 5,653 \\
$\mathbf{X}_{\mathbf{3}} \mathbf{Y}$ & $\mathrm{P}_{\mathrm{y} 3}$ & 0,423 & 5,370 \\
\hline
\end{tabular}

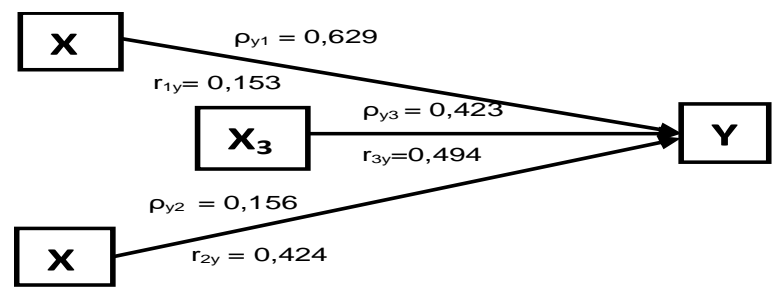

Fig 1. Path coefficient model

\section{Discussion}

The direct effect of pedagogical competence on teacher performance is proved to be correct or acceptable with positive path coefficient of $\mathrm{P}_{\mathrm{y} 1}=0.629$. The result of the relationship strength analysis between the variables of pedagogical competence (X1) and teacher's performance $(\mathrm{Y})$ reveals the value of $\mathrm{r}_{\mathrm{y} 1} .=0.391$. The significance test using $\mathrm{t}$ statistics at the level of confidence $\alpha=0.05$ and the degrees of freedom (1: 146) results in $t$ count $=5.134$. The t-table is only 1.645 and since the value of $t$-count $>t$-table, then the null hypothesis (Ho) is rejected. The result indicates a significant relationship between pedagogical competence and teacher performance. This is relevant to Rafiq Awan (2010) research conducted at the University Libraries Pakistan which stated that Pedagogic Competence affects performance[11]. Fransisca and Triana's (2016) research on the relationship of pedagogical competencies and teacher performance, analyzed that teachers with pedagogical 
competencies tend to be highly classified[12]. The direct effect attitude towards teacher performance is said to be correct or acceptable with positive path coefficient of $p_{\mathrm{y} 2}=0.156$. The result of the strength analysis of the relationship between attitude towards the profession (X2) and teacher performance $(\mathrm{Y})$ shows the value of $\mathrm{r}_{\mathrm{y} 2 .}=0.424$. The significance test using $\mathrm{t}$ statistics at the level of confidence $\alpha=0.05$ and the degrees of freedom (1: 146) yields t-count $=5.653$. Since the t-table is only 1.645 and the value of t-count $>\mathrm{t}$-table then the null hypothesis (Ho) is rejected. It means the relationship between the attitude towards the profession and teacher performance is significant. According to Paul K. Rotich, Richard K Ronoh, and Joseph M Mubichakani research on teachers attitudes towards the use of computers in education[13]., the direct effect of work motivation on teacher performance is proved to be correct or acceptable with positive path coefficient of $p_{y 3}=0.423$. The result of the strength analysis of the relationship between the work motivation (X2) and teacher performance $(\mathrm{Y})$ shows the value of $\mathrm{r}_{\mathrm{y} 3} .=0.406$. The test of significance using $\mathrm{t}$ statistics at the level of confidence $\alpha=0.05$ and the degrees of freedom $(1: 146)$ results in $t$-count $=5.370$. Since the t-table is only 1.645 , then the value of $\mathrm{t}$-count $>\mathrm{t}$-table. Based on this, the null hypothesis (Ho) is rejected, meaning that the relationship between work motivation and teacher performance is significant. This is in line with the Mahmudah Enny Widyaningrum (2011) study which concluded that motivation affects employee performance. And Beal and Steven's (2007) research on student motivation in completing school through the internet.

\section{Conclusion}

Based on the results of the three hypotheses test, the second hypothesis, on the attitude of teachers to the profession gives the smallest significance, Py $=0.156$. While the first and third hypotheses gave a large significance, known as the pedagogical competence hypothesis of Py $=0.629$ and the work motivation hypothesis for $\mathrm{Py}=0.423$. The results of this study indicate a positive direct effect on pedagogic competence, attitudes to the profession and work motivation on teacher performance. This means that teachers must improve pedagogical competence, have attitudes toward the profession and be motivated achieve good teaching performance.

\section{References}

[1] Robbins, SP.: Organization Theory Structure design and Applications. Division of Simon \& Sucher Englewood Cliftts. Jakarta. Arcan.pp. 135 (1994)

[2] PA. Satwika and F. Hilman.: Kinerja Karyawan Berdasarkan Keterbukaan Terhadap Pengalaman, Organizational Citizenship Behavior dan Kebudayaan Organisasi. Jurnal Psikologi Universitas Gajah Mada. Volume 41. pp. 4 (2014)

[3] Moorhead \& Griffin.: Prilaku Organisasi. Manajemen Sumber Daya Manusia Edisi 9. Jakarta. Salemba Empat.pp. 68 (2013).

[4] OrissonA.,Ryegard, T.Apelgren, K., Eriksson, R. A Swedish.: Perspectives on Pedagogical Competence, Sweden: Uppsala University, Division of Development of Teaching and Learning, pp.10. (2010)

[5] Wawan Dan Dewi.: Teori dan Pengkuruan Pengetahuan, Sikap Dan Prilaku Manusia. Yogyakarta, Nuha Medika.pp.20 ( 2010) 
[6] Saifudin Azwar.: Sikap Manusia, Teori dan Pengukurannya, Edisi 2. Yogyakarta: Pustaka Pelajar, pp. 4-5 (1995)

[7] George R. Terry.: Prinsip-Prinsip Manajemen. Jakarta. Bumi Aksara. pp.130. (2006).

Muhibin Syah.: Psikologi Pendidikan. Bandung: Remaja Rosdakarya, pp. 136 (2004).

[8] A. A. Anwar Prabu Mangkunegara.: Manajemen Sumber Daya Manusia. Bandung: PT. Rosda Karya (2005)

[9] A.Wawan dan Dewi. M.: Teori \& Pengukuran. Pengetahuan, Sikap, dan Prilaku Manusia. Yogyakarta: Nuha Medika. (2010)

[10] Rohan Singh, Madhuminta Mohanty, Mohanty.A.K.: Perfoemance Aprasial Practise in Indian Service and manufacturing Swactor Organization, Asian Journal Of Management. . Volume 4 Issue 2 (2013)

[11] Paul K. R, Richard K R, Joseph M M.:, International Journal Of Engineering And Computer Science, (ISSN:2319-7242 Volume 7 Issue 2 February 2018, Page No. 23597 Index Copernicus Value (2015).

[12] Fransisca VS dan Triana Noor EDS, Hubungan antara kompetensi Pedagogik dan Kinerja Guru, (Jurnal Humanika, Vol. 16, Nomor 1, September )2016)

[13] E. Mulyasa.: Kurikulum Berbasis Kompetensi. Bandung: Remaja Rosda Karya (2004)

[14] George R. Terry. : Prinsip-Prinsip Manajemen. Jakarta: Bumi Aksara (2006)

[15] Muhammad Awam Rafiq.: Leadership Style, Organizational Culture and Job Commitment. Saarbrucken, Deutschland. (2010)

[16] J Lekganyane, Eskom \& T Oosthuizen.: Analysing Leadership Traits in Establishing Effective Leadership at Eskom, Acta Commercii (2006)

[17] Mukhneri Mukhtar.: Jurnal Manajemen Pendidikan Universitas Negeri Jakarta (2010)

[18] Juli P K. R, Richard K R, Joseph M M.: International Journal of Engineering and Computer Science (2018). Volume 7 Issue 2 February, Page No. 23597 ISSN:2319-7242 Index Copernicus Value (2015)

[19] Moorhead dan Griffin.: Prilaku Organisasi Manajemen Sumber Daya Manusia Edisi 9. Jakarta: Salemba Empat (2013)

[19] Robbins, Stephen.: Prilaku Organisasi - Organization Behavior. Buku1Jakarta: Salemba Empat (2007)

[20]. Satwika PA, Himan F.:.Jurnal Psikologi Universitas Gajah Mada, Volume 41 (2014)

[21] R.A. Roe.: Journal European Psychologist. Washington, DC: American Psychological Association (2002) 